\title{
The righteousness of God, begging for the poor and Paul's apostolic mission according to his Letter to the Romans
}

\author{
Author: \\ Andries G. van Aarde \\ Affiliation: \\ ${ }^{1}$ Department of New \\ Testament Studies, University \\ of Pretoria, South Africa \\ Note: \\ Paper presented at the \\ Prestige FOCUS Conference \\ on Mission and Ethics \\ program, 14-16 September \\ 2011, University of Pretoria, \\ South Africa. \\ Correspondence to: \\ Andries van Aarde \\ Email: \\ andries.vanaarde@up.ac.za \\ Postal address: \\ Private Bag X20, Hatfield, \\ Pretoria, South Africa \\ Dates: \\ Received: 29 Jan. 2012 \\ Accepted: 13 Mar. 2012 \\ Published: 29 June 2012 \\ How to cite this article: \\ Van Aarde, A.G., 2012, \\ 'The righteousness of God, \\ begging for the poor and \\ Paul's apostolic mission \\ according to his Letter to \\ the Romans', HTS Teologiese \\ Studies/Theological Studies \\ 68(1), Art. \#1223, 8 pages. \\ http://dx.doi.org/10.4102/ \\ hts.v68i1.1223
}

(C) 2012. The Authors.

Licensee: AOSIS

OpenJournals. This work

is licensed under the

Creative Commons

Attribution License.
In Romans 15:22-33 (the concluding section of Paul's last written letter) 'the apostle for the gentiles' motivates his financial contribution (diakonia) to the poor (ptōchous) in Jerusalem in terms of his mission to the nations ( $t a$ ethne $)$. The aim of this article is to argue that Paul's notion, 'the righteousness of God' (diakaiosunē tou theou), mentioned for example in Romans 1:18-3:20, not only accentuates God's saving act (a vertical dimension) but also God's intervention on behalf of the poor and other outcasts through the apostolic mission (the horizontal dimension). The article explains Paul's use of the concept righteousness as a 'virtue' by focusing on both the Hellenistic moral philosophy and the occurrence of the term zedaqah in the Old Testament. For Paul, the revelation of God is the revelation of the righteousness of God ( $\operatorname{Rm~1:17)~in,~}$ among others, the Law (e.g. Ex 22:21-24), the Prophets (e.g., Zch 7:9-10) and the Writings (e.g. Job 24:9). Those affected, are the poor without patrons, women without patriarchs, children without parentage and foreigners without a paterfamilias. The pilgrimage to the nations includes all four groups of marginalized people. Blending the concepts 'the righteousness of God', 'begging for the poor' and Paul's apostolic mission helps us to understand why the end of Romans (15:22-33) and its beginning (1:18-2:20) come to full circle. The vertical dimension of God's saving act merges with the horizontal dimension of God's saving act.

\section{Righteousness - Paul and Matthew}

As someone who has focused strongly on Matthew's gospel during my active academic career, I have to admit that the lack of nuance in the way in which both Pauline and Matthean commentators compare Paul's use of diakaiosune (righteousness) with the occurrence of this notion in Matthew has always left me with a sense of unease. For me, it is difficult to accept that righteousness would mean something totally different to the 'Hellenist Jew' Paul, than it means to Matthew, another 'Hellenist Jew' - even if the current trend in some circles within Matthean scholarship, that considers Matthew's intentional message as combating an inheritance of a socalled 'law-free' gospel, which originated in Pauline circles in formative Christianity, is taken into account. On the contrary, I agree fully with Roger Mohrlang (1984:127) who says: 'Both [Paul and Matthew] are concerned to effect a radical form of ethical righteousness on a level deeper than the merely external' (author's emphasis).

The interpretation of the diakaiosune in recent new translations of Matthew, in terms of which 'righteousness' is understood as 'doing what is right' (cf. Louw \& Nida 1988:744) serves as an example. The Matthean added beatitude, 'blessed are you when you are persecuted because of your doing what is right' in Matthew 5:10 is such an example. This macarism is inflated by Matthew (5:12) by adding a reference to prophets who had also been persecuted in a way similar to the persecution of Matthew's intended readers. The identity of who the 'persecutors', could be, in Matthew's eyes, is revealed in the so-called anti-Pharisaic chapter in Matthew 23, where those who traverse oceans and territories to convert proselytes for Israel are labelled as zealots who actually lure the proselytes into misery (Mt 23:15). Here, one also finds reference to the killing of the prophets sent (apestalmenous) by God (Mt 23:37). An element of the same selfish righteousness is also mentioned by Paul in Romans 10:1-4. Here, Paul has his own 'kinsmen by race' (suggenōn mou kata sarka) in mind, in other words, 'Israelites' (Israēlitai) (Rm 9:3-4), who pursue a diakaiosunē, which is not God's righteousness (that is a righteousness established through faith), but a zeal for a righteousness of their own (idian dikaiosunēn) ( $\mathrm{Rm}$ 10:3).

\section{Righteousness and mission in Romans}

In Romans diakaiosune, often translated as 'justice' (Rm 2:3-16; 5:9-10; 8:2, 31-30; cf. Byrne 1996:21), is indeed very prominent. It is usually understood in terms of two significant semantic fields, namely that of 'association' and that of the 'court and legal procedures' (see Louw \& Nida 1988:452-453). Both these connotations seem to occur in the letter to the Romans (Hahn 2006a:271297; [1998] 2006b:305-308). For Paul, this means that, on the one hand, Christ died for sinners 
and existentially this means an acquittal of transgressions (the legal aspect). ${ }^{1}$ On the other hand, the diakaiosune refers to sinners who are put in the right relationship with God (the association aspect). However, these two connotations are closely related to each other. One can even say the former (the legal aspect) is directed to the latter (the association aspect). The latter is the result of the former: the sinner is acquitted and is therefore put in the right relationship with God; that is, a distorted relationship is restored and it is no longer blocking the free association between God and humankind. ${ }^{2}$

For Paul, being a slave of sin is to exist kata sarka, destined to failure, corruption and transiency. This is, for example, expressed in the first sentence ( $\operatorname{Rm~5:1)~of~the~second~part~}$ (Rm 5-8) of the paraenetic part of the body of the letter to the Romans: 'Because we believe in the right relationship with God there is peace between us and God and our Lord Jesus Christ.' Focusing on the outcome of the salvation act of God in Romans 5:9-11, it becomes clear that the notion of reconciliation is almost used synonymously with the idea of the right relationship established with God. In a particular sense of the word, mission in Pauline terms, is to accomplish the righteousness of God (hédiakaiosune tou theou). This is what 'being an emissary, an apostle', is about for Paul - instigated 'to bring about the obedience of faith among the ethne for the sake of the name of Jesus Christ our Lord, because he as Jesus' envoy received charis and apostleship on account of Jesus himself who passed away his kata sarka existence and passed on his kata pneuma existence (Rm 1:1-5). The core of this 'missionary declaration' is to be found in Romans 1:3-4, and my own interpretative translation thereof is:

The gospel is about God's son, who in terms of being a mortal human being (kata sarka), was born from the seed of David; at the same time he was destined by God to be the son of God - and this by virtue of God's power in terms of the spirit of holiness (kata pneuma agiōsunēs), as a result of his resurrection from the dead - Jesus Christ, our Kyrios.' ${ }^{3}$

1.In Romans 3:24-26 Paul explains salvation from sins in terms of sacrificial terminology (see Dunn 1998:216-223). However, Cilliers Breytenbach (1989:202203, 215, 221; cf. 1986:696-704) argues that Paul does not understand the death of Jesus as a sacrifice. In his book Paulus: Leben und Denken, in the chapte entitled 'Jesus Christus als Retter und Befreier', Udo Schnelle (2003:494) writes: '[D]ie Vorstellung des "Loskauf/Freikau" apolutrōsis in Röm 3,24; exapsorazō in Gal 3,13; agorazō in 1 Kor 6,20; 7,23) bringt die Befreiungstat Jesu Christi prägnan zum Ausdruck: Jesus Christus nahm auf sich, was die Menschen in Unfreiheit hält, er zahlte 'für uns' den Preis der Befreiung von der Mächten der Sünde und des Todes'(cf. Strecker 1979:229-259; Van Aarde 2005:222-243).

2.Reffering to Philippians 3:9 Hahn (2006:304) puts it as follows: 'Es geht um die heilstiftende Gerechtigkeit Gottes und um dere unlösbare Relation zum Glauben; aufgrund des Glaubens und im Glauben wird sie wirksam ... Rechtfertigung aufgrund des Glaubens und Zugehörigkeit zu dem aufertstandenen Christus stellen eine Einheit dar. Die Aussagen über das Sein "in ihm", in Jesus Christus bzw, in seinem Leib, stehen nicht in Spannung zu den Aussagen über die Rechtfertigung, sondern Leib, stehen nicht in Spannung zu den Aussagen über die Rechtfertigung, sondern
sind für ihn notwendiges Korrelat. Sie zeigen darüber hinaus, daß Rechtfertigung nicht nur eine Deklaration, sondern eine wirksame Erneuerung is.'

3.A.B. du Toit ([1992] 2007:242) quite correctly says with regard to Romans 1:3-4 'It would be incorrect to read this statement as happened so often in the past, in terms of a two-nature Christology. Not only would this be entirely anachronistic, the reference to the resurrection of Jesus in the second member of the parallelism shows that a chronological sequence is envisaged. Our confession [is based on] a dynamic Christology consisting of two phases, with the resurrection marking the transition from the one to the other. This also excludes an understanding of the transition from the one to the other. This also excludes an understanding of the two phases as a reference to the physical, outward and the spiritual, inward sides of Jesus' earthly, pre-resurrection life.' In 1946 my own predecessor, professor A.S Geyser, also argued that Philippians 2:6-10 should be interpreted in the same vein as Romans 1:3-4 as denoting Pauline dialectical antinomian categories, vis-à-vis 'flesh-spirit, 'ncarnation-resurrection', 'humiliation-elevation' etc. (see Geyse 1946:190; Van Aarde 1992:164). For this exegesis Geyser faced a heresy charge, and he vacated his position at the University of Pretoria in 1961.
The question, however, is whether for Paul righteousness does not imply something more than passing on authentic renewal of life. If so, one could affirm a stronger familiarity between Matthew and Paul with regard to their understanding of being both ethical and having a zeal for inviting outcasts into God's inclusive 'new Israel' (Gl 6:15-16), that is, God's 'new creation', the 'Israel of God'. Specifically, with regard to Paul's letter to the Romans, both James Dunn (1988:743) and Bruce Longenecker (2007:53) agree that Douglas Moo, in his commentary, is right about Paul's reference in Romans 12:13 to a contribution to the 'needs (chreiais) of the saints' that the 'fellowship we are called here is the sharing of our material goods with Christians who are less well-off', but that Paul does not have the collection of money for the poor in Jerusalem to which he refers to in Romans 15:25, 26 and 15:30-33 'particularly in mind', the apostle, however, does 'not of course exclude these Christians' (Moo 1996:778-780).

Nearly three decades after Paul, Matthew (28:16-20) still valued the same ideal of reaching out to all nations (Mt 28:16-20). The Matthean Jesus regarded the 'Christfollowers' - associated with the twelve or eleven disciples - as still being part of Israel. The question, however, arises how Matthew thought outsiders could become members of the 'new Israel'.

Ed Sanders (1992:262) sheds light on this question. Sanders introduced the concept 'covenantal nomism'. ${ }^{4}$ By means of this notion he explains how people came to Israel on account of divine grace, and how Israel remained an ethnic entity. One remained part of this particular ethnic group by obeying the Torah. This two-in-one event - becoming part of Israel on account of God's grace, and remaining obedient to the law - is encompassed by the term 'covenant'. Two parties are at work here: one taking the initiative and bringing you in; the other responding by ensuring that Israel continues to exist. In an earlier work, Sanders (1997:422) emphasized that participation in Israel did not depend on merit. Such a perception would amount to a caricaturing of Israel's religious convictions. Entering the covenant is through God's grace. The two-in-one-event, grace and obedience, is not brought about by any human merit, but is solely the result of the righteousness of God. When the word 'justice' is used in Israel's literature, 'covenantal nomism' is at stake: God does what is right and you do what is right; God loves you, and you love one another.

Paul's saying, quoted from Habakkuk 2:4, stating that you cannot be saved by 'justice' based on obedience to the law, but only on account of your faith in God (e.g. Rm 1:17), does not open the door to portray Israel unfairly as if they believed that they earned their salvation and that Paul now needed to rectify the matter by declaring that living in the right relationship with God was a divine act of mercy only. We are

4.In 2009 Sanders responded in an article entitled 'Covenantal nomism revisited' to his critics. According to Sanders the criticism is based on the arguments that the notion is not supported by several other themes in rabbinical writings; that the notion, though it occurs in some rabbinical literature, is not so central at all; and notion, though it occurs in some rabbinical literature, is not so central at all; and
that, though it occurs, it is contradicted in some other writings by opposing notions such as the so-called 'Merit theology' (see Sanders 2009:25-55). 
dealing here with a far more profound issue. If 'justice' is to be understood as linked solely to obedience to the law, then one's life is in bondage, enslaved to fallible socio-cultural conventions. Paul implicitly asks the 'Christ-follower' to leave the kata sarka existence behind and to embrace the kata pneuma existence.

\section{Righteousness and ethics}

Seeking authentic life in terms of transient things constituted a life kata sarka which is tantamount to not seek the living God. This is a form of idolatry which is not based on the righteousness of God (see for example Rm 10:3; cf. 1 Th 1:9; Phil 2:11; Rm 14:11). ${ }^{5}$

Teresa J. Hornsby (2001), in an essay entitled, 'Paul and the remedies of idolatry: Reading Romans 1:18-24 with Romans 7', writes:

When Paul asks in [Romans] 7:24, 'Who will rescue me from this body of death?' he is also asking how to transform the lifelessness of the transgression (i.e., the tension between Law and Sin) into a relationship with God. And his answer comes from verse 25: 'through Jesus Christ our Lord.' The crucifixion as sacrifice is a response or remedy to idolatry, that is, the people's failure to connect with God through God's creation and through the Law. Paul, therefore, opens access to God through the sacrifice, that is, the crucifixion ... In Romans 7 and 8 ... Paul evokes a sacrificial image of the human. Through the violent and filthy sacrifice, or at least through its invocation in his text as a response to idolatry, Paul sets up a way in which the Sacred and flesh are forever joined. In Romans 1:18-23, Paul tells us that the Sacred in their own creations were lifeless copies of God's creatures. Thus, it was human agency that denied a sacred presence to God's creatures. (p. 231)

For Paul, idolatry pertains to seeking authentic life in things of created nature and that is a life that seeks happiness in what is human, in other words in human behaviour and in human conventions, norms, and rules. Such a life is a selfish life. It is about self-preservation because it puts the individual as a person in the centre. This, Paul calls self-righteousness (Rm 10:3). And although it may appear very pious, it is still futile. In this instance, Paul clearly refers to the 'righteousness of God' in the context of the Septuagint. According to Louw and Nida (1988:452), Paul uses dikaiosune in the context of the covenant relationship rather than in the context of legal procedures. Dikaiosune can also be understood as 'to give to those in need as an act of mercy'; 'acts of charity, alms, giving to the need' (Louw \& Nida 1988:570).

God's justice is not the righteousness of human beings. In this regard, Hosea 11:9 also comes to mind: 'For I am God, and not a human being.' God's righteousness refers to an affirmative action undertaken to do what Israel was unable to do to those

5.In Philippians $2: 11$ and Romans 14:11 Paul builds his argument on $L X X$ Is $45: 23$ egō eimi ho theos, kai ouk estin allos ... legōn dikaiosunēn kai doxa pros auton exousin. 'The all-determining relationship to the Lord means that, as "slaves", we are accountable to him and to him alone' (Byrne 1996:410-411). With regard to the issues of tolerance to the 'weak in faith', 'eating and non eating', 'judging one day more significant than others' (Rm 14:10-12), and 'resolving conflict among fellowbelievers' (Phil 1:27-30), Brendon Byrne (1996:410-411) states: 'Paul reinforces [christology stated in eschatological form] with a quotation from Isa 45:23. The text triumphantly proclaims the coming submission of all creation to the rule of Israel's God. It appears, with a more explicitly Christological reference, in the final stanza of the hymn in Philippians 2; 6-11. outside, and that is to accommodate outsiders, those who were regarded as not belonging to God and the ecclessia They are the uncircumcised foreigners who do not belong to Israel, the poor, reduced to the status of beggars (see the Lucan parabolic story in Lk 16:19-31 about Lazarus, whose name means 'God helps'), children who find themselves without the shelter of a household to survive, women who, in the absence of a man who could exercise control [sic] over them, have no support in life. If the hierarchy failed to provide a safeguard, the fatherless children, the allogenai (cf. Lk 17:18), the widows and the poor would become the objects of God's compassionate justice (see Crossan 1998:182-208).

Thus seen, missioning apostleship concerns diakonia and koinonia. When Paul speaks of the 'righteousness of God', I think, we are homing in on what lies at the heart of Paul's debate with those among the earliest 'Christ-followers' who were convinced that religious leitourgia was tantamount to being culture-oriented. Over against them Paul became convinced that he was the apostle to the outsiders, and that he was imitating Jesus in doing so. Furthermore, by understanding Paul's missioning apostleship in this way, is to understand why he was campaigning tirelessly for the poor in Judea while proclaiming obedience of faith among the $e t h n \bar{e}^{6}$ for the sake of the name of Jesus Christ our Lord, because he, as Jesus' envoy, received charis and apostleship on account of Jesus himself who sacrificed his kata sarka existence and passed on his kata pneuma existence (Rm 1:1-5).

In the New Testament Matthew is the author who speaks of 'God's justice' almost as often as Paul does (see e.g. Przybylski [1980] 2004). As was mentioned earlier, scholars often point out that Matthew and Paul do not use the same language when it comes to this matter (see e.g. Sim 1998; 2002:767-783). This, to me, is a false presumption (cf. Harrington 2008: 11-26), especially with regard to the accommodation of the so-called 'outsiders'. Matthew and Paul share the same thinking, although they express it in their own nuanced manner (see e.g. Gundry 2005:117-118; Meier 1983:12-86). Matthew is the one who pointed out that his understanding of justice was vested in what he could learn from Jesus. Jesus was the one who said that God made the sun rise on those inside and those outside (Mt 5:45). Jesus was the one who said that showing less love towards those on the outside could not be justified (Mt 5:43-44; 22:39). This is also Paul's understanding ( $\mathrm{Rm}$ 12:16-18). Matthew says that one's righteousness should be more than that of the upholders of the old covenant theology. Here, 'more' does not mean more good deeds in a quantitative sense. This 'more' is meant qualitatively to refer to something 'quite different', where 'different' is similar to what Paul is referring to when he speaks about a humankind which is newly created, that is, the 'Israel after the flesh' transformed into 'an Israel of

6. Referring to the reference to the financial contribution to the 'holy poor' in 2 Corinthians 8 and 9 as a formal cultic act (leitourgia), Martin Vahrenhorst 2 Corinthians 8 and 9 as a formal cultic act (leitourgia), Martin Vahrenhors (2008:220-222) is convinced that Paul (similar to Luke's report on the apostle convent in Acts 15:20) thinks of both Jerusalemites and people amongst the nations. Vor diesem Hintergrund halte ich es für wahrscheinlich, dass Paulus sich hier an den Sprachgebrauch hält, der hinter der Tradition des Aposteldekrets steh - auch wenn er selbst eine Heiligkeitstheologie vertritt, die auch heidenchristliche Gemeinden vollgültig als "Heilige" und nicht nur als christliche Beisassen ansieht' (Vahrenhorst 2008:222). 
God' (Gl 6:16). The 'Israel of God' consists of people who no longer seek justice in terms of obeying what is human and conventional, but in terms of the 'law of Christ'. This similarity between Paul and Matthew becomes clearer when one acknowledges that the Hebrew/Aramaic equivalent of diakaiosune is zedaqah. The meaning of zedaqah is 'equity in the administration of justice' (Davidson 1967:640).

\section{Diakaiosunē as virtue}

Paul's understanding of righteousness is expressed in the language of both his worlds: the eastern Mediterranean Semitic and the western Mediterranean Greco-Roman world (cf. Den Heyer 1998). For Plato and Aristotle righteousness (dikaiosunē) was of supreme value (aretē). Lists of virtues and vices played an important role in Hellenistic moral philosophy (see, among others, Engberg-Pedersen 2003: 608-634; cf. Malherbe 1986:79-85; 1992:267-333; Charles 2000:1252-1257). In Pauline literature, such lists (see 1 Cor 5:10-11; 6:9-10; 2 Cor 6:6; 12:20-21; Gl 5:19-21, 22-23; Phil 4:8-10; Rm 1:29-31) should be seen against the background of Paul's use of the terms 'hope' (elpis) and 'righteousness' (dikaiosune). Hope is based on righteousness (dikaiosunē) and peace (eirēnē) (Rm 5:1). Righteousness and peace, in turn, are based on reconciliation (katallagēe) (see Rm 5:9-10). Hope creates an expectation of the future as can be seen in Paul's use of the grammatical futurum construction in Romans 5:9 and 10, and Paul's reference to an apocalyptic expectation in Romans 8:18 (see the expression pros tēn mellousan apokalufthēnai).

It could be said that the Pauline letters contain a 'theology of hope'. Ferdinand Hahn (2002; see Breytenbach 2011:181) summarizes 'the gospel according to Paul' as a 'witness to hope' (Zeugnis der Hoffnung). In the Letter to the Romans (8:24a) Paul says: 'For hope we were saved' (tē gar elpidi esōthēmen), and in the Letter to the Galatians (5:5): 'we ourselves eagerly wait for the hope of righteousness' (elpida dikaiosunēs apekdechometha). His understanding of calling (kaleō) ( $\mathrm{Rm} \mathrm{8:30)} \mathrm{is} \mathrm{similar.} \mathrm{Calling} \mathrm{is} \mathrm{also} \mathrm{connected} \mathrm{to}$ righteousness (dikaioō) (Rm 8:30). For Paul calling, hope and righteousness are not simply theoretical matters. He is well aware of the real world and its corruption, pollution, illness, war and death (see Rm 8:31-39). Though fully aware of this reality, he is nevertheless convinced that there is hope for the future. He sees hope as follows:

- it adds value to life (Phil 4:8)

- it serves others in love (dia tēs agapēs douleuete allēlois) (Gal 5:13)

- it contributes to well being (tèn heautōn sōtērian kategergazesthe) (Phil 2:12)

- good is done impartially (ou gar estin prosōpolēmpsia para tō theō), by all (be that Jew or Greek) and to all (be they Jew or Greek) (panti tō ergazomenōn to agathon) ( $\mathrm{Rm} 2: 9,10,11)$.

By the time Paul started writing there was already an established philosophical tradition regarding the understanding of the 'hope of righteousness'. This tradition came mainly from Plato via Aristotle. According to Plato there should be order in state affairs (res publica), which can only be possible if there is also order in the human psyche, in the lives of individuals. The core of order in the public and individual domains is value (aretē) that is added to life. People should focus on what is right and valuable. Righteousness (dikaiosune $\overline{\text { ) }}$ is the core value (inherent in arete $\bar{e}$ and it determines all other values [Plato, Respublica I, in Burnett \{1900\} 1967, II.327a-621d]; the totality of arete [Aristoteles, Ethica Nicomacheia, V.1130a9]). Ferdinand Hahn ([1998] 2006:300) speaks of 'Kardinaltugenden'. He points out that it was Paul's contemporary, Philo Judaeus of Alexandria, who during 1 вCE -1 CE began to use the concept 'righteousness' within the context of this Greek meaning (Hahn 2006b:301-302).?

Dikaiosune encompasses all other values so that order can come to the res publica, and the lives of individuals. Aristotle (Ethica Nicomacheia I.xiii.19, 1103a 3-7) explains this in terms of a specific ethos. He agrees with his mentor, Plato (Respublica IV), that what is right (dikaiosune $)$ determines the 'ethical character' (to êthikon) of the psyche of the people (Ethica Nicomacheia I.xiii-II); it is the core of all virtues and binds them together. According to Engberg-Pedersen (2003:611), three characteristics are present (Aristoteles, Ethica Nicomacheia II.v.3, 1106a1-2):

- Passion (pathos): ethos is ignited by the passion to do what is right. If caring and compassion lack, corruption causes chaos.

- It is not possible to care passionately without energy (energeia). This energy dynamically (dunamis) leads to action (chrēsis).

- Value creates a 'state of mind' (hêxis), a specific mentality. However, if this state of mind or mentality does not translate into dynamic action, it is no longer valuable or right. Both Plato and Aristotle call the core of this value (aretē) dikaiosune.

Paul often includes lists of virtues and vices in his letters, but the only instance where the word 'value' (aretē) is used, is in Philippians 4:8: What more can we say? Whatever is true, whatever is honourable, whatever is just, whatever is pure, whatever is lovely, whatever is commendable, if there is any excellence (aretē) - this, according to Paul (Phil 4:8) - and Aristotle (Ethica Nicomacheia II.3.1106a1-2) - deserves to be commended (epainos). A follower of Christ should focus on all of these things (tauta logizesthe).

Similar values are commended in Hellenistic moral philosophy. This begs the question: What is the difference between the ethics of Christ-followers and that of others? According to Paul, there is a radical difference. This lies in the peace of God (he eirēnē tou theou) - the harmony between the one who is 'in Christ' (in an unencumbered intimate

7.'Es gibt aber andere Schriften, die teilweise in die Septuaginta aufgenommen worden sind, die wesentlich starker das griechische Gerechtigkeitkeitsverständnis

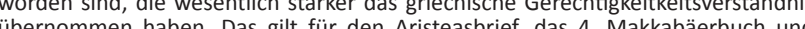
ubernommen haben. Das gitt fur den Aristeasbrief, das 4. Makkabaerbuch und auch die Sapientia Salomonis. Ganz bewußt hat Philo vom Alexandrien eine Verschmelzung der biblischen mit der (mittel)platonische Tradition angestrebt, so daß das Verstandnis der Gerechtichkeit als Tugend bei inm in den Vordergrund trat. Ähnlich hat Josephus die Gerechtigkeit nur noch als zwischenmensliches Verhalten verstanden, hat jedoch anderseits die "Frömmigkeit" nicht zu den Tugenden gerechnet, sondern auf das Göttesverhältnis bezogen' (Hahn 2006b:301-302). 
relationship) and in God. This peace radically transcends (huperechousa) all convictions (voēmata) (Phil 4:7). It differs from all other values or anything else that could be deemed valuable. To be in such an intimate relationship with God, supersedes radically anything that can be imagined or that can be deemed beautiful. This radically different peace, this new relationship, becomes the safe haven for the emotions (hearts) (tas kardias), the psyche and the convictions (ta onemata) with regard to public responsibilities, the res publica, the politeuma (Phil 3:20).

So what now? Now that we know that we are different, what next (to loipon) (Phil 4:8)? Everything that is in harmony with this new relationship should be 'true' (alēthē). For Paul, 'what is true' is not what a court has proven to be true instead of false. Truth is what is true according to the new conscience (suneidesis). It is about knowing together and being together with God in the midst of the public world (politeuma). Truth is authenticity, congruence, integrity. A system of values is true because the believer is part of God's new world, because Christ Jesus died to the old world, which means that the old value system has passed and was replaced by a new one (which Aristotle called ethos or ethics). That is why the believer is a different person with a new character (to ethikon). The ethics of the believer will be in accordance with what Christ renewed. This truth is that which is new, 'honourable' (semna). According to the old value system, by honourable (semnos) was meant to conform to the traditional system, to a natural life (a sarkikos existence). The new politeuma consists of a new value system that redefines what is 'lovely' (prosfile $\overline{\text { ) }}$ and 'pure' (hagna). Vahrenhorst (2008:83) shows that the word hagnos is used also as synonym for dikaios, similar to hagneia for dikaiosune (p. 83, n. 59). In religo-poltical context hagnos could refer to the polis which replicates the 'purity' attached to the temple (see Williger 1922:59, 66-68). However, the very codes of honour and shame were transformed on account of the death and resurrection of Christ Jesus. The new value (aretē) is commendable (epainos). Dikaiosune remains the core, though now, that which is right (hosa dikaia) and reputed to be good (hosa eufēma) (Phil 4:8), is no longer 'self-righteousness' (tēn idian dikaiosunēn), but the 'righteousness of God' (tēn tou theou dikaiosunen ) (Rm 10:3). Christ is the one who brought about the change ( $\mathrm{Rm} 10: 4)$.

According to Paul, that which has value has nothing to do with one's own accomplishments; it is not generated by people themselves; it is given by God. Jesus is the gift (dōrea) of God ( $\mathrm{Rm}$ 3:24). What is of true value does not merely concern the own psyche, but is about relationship with others, the ekklessia, the faith community. As a member of this body, the believer brings about change in the lives of individuals and the faith community in the world - change for the better. In Romans 15:31, Paul uses the word dorroforia to refer to his 'bringing of gifts to Jerusalem', which are 'acceptable to God's people' (Louw \& Nida 1988:568).

\section{Righteousness and Zedaqah}

In the first-century Mediterranean social world, the term 'justice' has both a 100 percent religious and a 100 percent political and economic connotation. Divine justice, social justice and purity are three threads of the same fabric. In a hierarchical patron-client context, 'justice' towards the poor is the honourable responsibility of the patron. Where this is refused, the righteousness and God is prompted - either in prophetic announcement or in divine intervention. This divine justice is witnessed (see Crossan 1998:182-208) in the Pentateuch, the Prophets and the Writings of the Tanach, e.g. Exodus 22:21-24, Zechariah 7:9-10 and Job 24:9 respectively.

According to Paul, Jesus is 'object of "hope" for "all the nations" because the exercise of his "lordship" is destroying the forces of $\sin$ and death and preparing the way for the final kingdom (1 Cor 15:24-28; Phil 2:9-11)' (Byrne 1996:430). In his commentary on Paul's letter to the Romans, Brendan Byrne also describes Paul's use of 'texts from all three parts of Scripture (the Law [Deut 32:43 in 15:10], the Prophets [Isa 11:10 in $\mathrm{v}$ 12] and the Writings [Psalm 18 in $\mathrm{v}$ 9b; Psalm 118 in v 11])' (Byrne 1996:430). Indeed, divine justice encompasses references to Israel's memoirs of creation (read Gn 18:19, Ps 33:4-7, Ps 99:4, 7 and 103:6-7, Ps 96:11-13), the 'books of Moses' (read Ex 22:25, 26-27; 23:10-11, 12; Dt 5:12-15; 23:19; 24:6, 10-11; 15:1-2, 7-11; 19:14; 24:19-21; 27:17; Lv 19:9-10; 25:2b-7, 35-37, 29-32), the Prophets (read 1 Sm 8:14-18; Am 2:6-8; 5:7, 10-12; 8:4-7; Hs 6:6; 12:7-9; Is 1:1-17; 3:14-15; Mi 2:2, 3:1b-3; 6:6-8; Ezk 45:9-12; Zch 7:9-19; Jr 7:5-7; 7:9-11), the Writings (read Job 29:14, 12-17; Pr 22:22-23; 23:10; Ps 89:14; 72:1-4; 106:3; 82:1-8).

It has already, and on many an occasion been pointed out that the ethics of Paul already existed in Hellenistic and Israelite circles (see e.g., Malherbe 1986, 1992). However, this does not imply that there is no such thing as a specific ethics and morality enacted by the followers of Jesus Christ. Paul's understanding of the theological meaning of Jesus' death resurrection indeed gave new content and meaning to his ethics. Helmut Koester (2007), in his book, Paul $\mathcal{E}$ his world: Interpreting the New Testament in its context, writes the following:

What then are the criteria of ethics and morality in this new community? All those things that any society and its legal code would condemn, like murder, theft, and prostitution, are presupposed as unacceptable. The laws of a society or nation are to be respected unless they are immoral and discriminatory ... What matters - and all that matters - is the question how one relates to one's brothers and sisters in the community of the new age that endeavors to make God's justice a reality already now in this world. Here only principle determines what its members have to do: to follow the commandment of love regardless of all distinctions of ethnic, social, and gender identity ... It is not a new religion that Paul wants to establish - a new religion with all its boundary definitions and rules of exclusion. Nor is there any interest in the building up of personal piety (this term never appears in the genuine Pauline letters) or in the creation of righteous and moral personalities banding together in their pride of religious devotion, in their self-righteousness that makes them superior to others, in their assurance of having their personal sins forgiven, and sure that they have the right to judge others ... It is a new just society that the apostle envisages. Personal righteousness, piety, and moral achievements no longer 
matter. Justice and righteousness belong to God ... God is love, and his justice becomes a reality among all those who venture to accept this offer by becoming members of the new worldwide community of those who love each other and care for each other regardless of any racial, ethnic, gender, sexuality, and socialstatus distinctions. Righteousness as personal piety and morality only creates divisions within a society and among nations. The justice of God cannot be realized in this way. It can become real already here and now in a society without hierarchs who try to enforce divisive moral obligations, and without the borderlines of traditions that are reinforced by pious self-righteousness. God's righteousness is the gift of freedom - even freedom from piety and particularly from moral self-righteousness. It requires the establishment of justice among people who are free to abide by the standards of mutual respect, equality, and carrying one another's burdens. (p. 12-14)

\section{Righteousness and friendship}

It is clear that Paul transforms his ethics in light of his existential understanding of the meaning of Christ's death and resurrection. Tolerance replaces vengeance. Those who believe in Christ crucify themselves too (Gl 2:19). According to Aristotle's Rhetorica, deeds which call for vengeance are those by which someone else is regarded as being without 'worth' (in other words 'dignity'). Aristotle ([1959] [1964], in Malina and Pilch 2007:143 note 4) is of the opinion that three types of deeds call for vengeance, namely contempt (katafronessis), malice (perasmos) and insult (hubris). Holding someone in contempt, means robbing that person of his or her dignity, because he or she is regarded as being without worth. To act in a malicious manner, means to put stumbling blocks in someone's way in such a manner as to thwart that person's efforts. To insult somebody, means to cause that person harm, injury and inconvenience resulting in the person being dishonoured by a malicious person who regards him or herself as superior (Malina \& Pilch 2007:143).

Contrasting with such enmity is the singular concept of 'friendship' (filofronesis). ${ }^{9}$ It is this concept that formed the most important element of the genre comprising the Hellenistic private letter (see Doty 1973:11-12). Credit must be given to Robert W. Funk (1967:249-268) for having realized that it is on this score that Paul brought about an extraordinary transformation (see also Koester 2007:18). Instead of using the traditional topos 'filofronēsis', he began using the term 'parousia' to express his expectation to once again see the readers of his letter, with the intention of doing good (cf. Gl 6:10), as can be expected of 'friendship'. For Paul, the Spirit of God becomes the integrating force in the life of the believer so that it could be said that the Spirit is life to the believer and life is the Spirit.

8.Malina and Pilch (2007:143 note 4) point out that the following pronouncement is found in the Loeb edition of Aristotle's Rhetorica: 'In Attic law, hubris (insulting, degrading treatment) was a more serious offense than aikia (bodily ill-treatment). It was the subject of a State criminal prosecution (grafē), aikia of a private action (dikē) for damages. The penalty was assessed in court and might even be death. It had to be proved that the defendant struck the first blow' (Loeb 174-75).

9.'Modern scholars have identified three characteristics of Graeco-Roman letters. These are "philophronesis", "parousia" and "homilia". Letters are the expression of a the letter writer addresses the recipient as though physically present (parousia) and the writer continues the dialogue begun while the two parties were present and the writer continues the dialogue begun while the two parties were present
(homilia). The use of established epistolary formulas, often noted by scholars, (homilia). The use of established epistolary formulas, often noted by
served to reconnect the writer and the recipient' (Harding 2003:113).
Paul relativizes 'friendship' (Koester 2007:18). It is neither himself (or his 'presence' in the form of his letter) ${ }^{10}$, nor his friendship that serves as encouragement to those who suffer because of the contempt, malice and insult of evil people, but it is the presence of the Lord in their lives that encourages them (cf. 1 Th 4:13-18 in particular). This transformation is closely linked to the fact that Paul refers to the believer as en Christō, en Kuriō, and en pneumati. For Paul these formulae are filled with concrete life and meaning. In Paul's letter to the Romans (6:4), 'walk according to the Spirit' refers to conduct. Byrne (1996) puts it as follows:

To 'live according to the Spirit' is to allow one's life to be transformed and rules by the dynamic power of the new age, released by God's act in Christ and, in fact, tantamount for Paul to the influence of the risen Lord (cf. 1 Cor 15:45) ... 'Flesh' and 'Spirit' do not denote separate elements in the make-up of human individuals ('body' and 'soul', for example) but rather two possibilities of human existence - the one self-enclosed, selfregarding, and hostile to God, the other open to God and to life' (author's emphasis). (p. 238)

Therefore, it comes as no surprise that in his last letter, the one to the Romans, Paul commences his paraenesis with an appeal to the readers to offer themselves as a living and sacred sacrifice to God and to not conform to the standards of the world (Rm 12:1-2). In brief, Paul's understanding of what it means to lead a Christian life can be described as a life lived with full commitment and total dedication to God. The words about love in Romans 13:8-10 are well known. As is the case in Galatians 5:14, these words summarize the entire Decalogue - just as it is encountered in the Jesus tradition. The words at the beginning of this pericope, namely that one should be under no obligation to anyone, except the obligation to love one another ( $\mathrm{v} 8$ ), are particularly noteworthy. According to Paul, believers always have to love one another and all people - and this applies to the present and the future. Their love for one another and for all arises from a spontaneous gratitude towards God before being and without having been commanded to love. Robert Jewett (2007) explains as follows:

While some would argue that Paul follows the traditions of Hellenistic Judaism in this emphasis, the frequent citations of Lev 19:8 by early Christian writers make it likely that Paul is following a tradition established by Jesus, who gave unique importance to the law of love, as Mark 12:31 and parallels indicate. Paul takes an independent line with this tradition, as usual; treating it as no other NT writer did as a summary of the law, and contextualizing it within the local Christian community by the peculiar wording of 13:8. This results in a redefinition of ton plēsion ('the neighbor') ... Here it refers concretely to the Christian neighbor of whatever cultural background, ordinarily a member of one's small house or tenement church, but also including the 'other' of v. 8 who may belong to another congregation ... The command to love aims at mutuality, with each aiming to meet the needs of others as well as oneself, as the wording of 13:8 concerning 'love one another' makes plain. (p. 813)

This again emphasizes that the restored relationship with God brings about a radically new way of life in a totally new

10.In most instances the term, parousia, refers to the return of a human (e.g. 1 Cor 16:17; 2 Cor 7:6; 10:10; Phil 1:26; 2:12) - in the latter three examples, parousia refers to Paul revisit, but further on in 1 Thessalonians, the apostle is not referring to himself, but is pointing to the parousia of the Kurios (1 Th $2: 19 ; 3 ; 13 ; 4: 15 ; 5: 23$ ). 
dispensation - the dispensation of the Spirit ( $\mathrm{Rm} \mathrm{8),} \mathrm{a} \mathrm{new}$ dispensation which is contrasting a previous one, ${ }^{11}$ the life of 'old humankind'.

\section{Righteousness and Paul's collection}

This brings me back to Paul's letter to the Romans, his strategic missionary vision and his ethics. What would the purpose of writing the Romans letter be? Could it simply be to prepare the way for his journey to Spain (Rm 15:24)? That Paul intended to work in the West, cannot be denied. However, whatever his intention may have been, he, in all probability, finds himself in Corinth at the turning point of his so-called third missionary yourney (cf. Ac 18:23 ff). He sees his task in the eastern part of the Roman Empire as being accomplished. This includes his collection for the poor in Judea (comparing the two 'collection' chapters in 2 Corinthians 8 and 9) (see Joubert 2000). According to the concluding section of Paul's last written letter, he was writing just before setting out to take the financial assistance to the poor in Judea (see Rm 15:25; cf. Gl 2:10; 1 Cor 16:1; 2 Cor 8 and 9). In many ways he is already an experienced and seasoned apostle, but would not have the privilege of preaching the gospel of freedom in Christ for much longer.

Though the reason for the Lutheran notion that 'righteousness' forms the Mitte in Paul's kerygma, cannot be upheld today, the concept 'equity in the administration of justice' remains firm in the apostle's zeal to be Christ's apostle till the last days of his life. Hahn (2006b:303) puts it as follows: 'Es ist in jedem Fall festzuhalten, daß die Rechtfertigungslehre ein integraler und zentraler Bestandteil der Verkündigung des Apostels ist.' Paul's letter to the Romans was his last opportunity to give testimony of this zeal, his last writing to be written in freedom. It is clear from this letter that, at the time of writing, he experienced a considerable degree of tension, anticipation and uncertainty, especially in connection with his proposed visit to Jerusalem. His disposition, in his own words, twofold. Firstly, there was a concern that the 'unbelievers in Judea' would harm him, and secondly, there was uncertainty about how the believers would receive his collection for the poor (Rm 15:31). In the midst of these outward circumstances of concern and uncertainty, his strength, faith and resoluteness remained evident, and remarkable, to say the least. All of this is characteristic of a man who could say with conviction: 'In Christ Jesus I am proud of my service performed for God' (Rm 15:17). This service was performed not for the sake of self-righteousness, but because of divine justice.

\section{Résumé}

In Romans 15:22-33 the 'apostle for the gentiles' motivates his contribution (diakonia) to the poor (ptōchous) in Jerusalem in terms of his mission to the nations ( $t a$ ethne $)$. The aim of this essay is to argue that Paul's notion of 'the righteousness

11.Johan Vos (2005:103) puts it as follows: 'De opstanding der doden betekent voor Paulus de metamorfose van het verganklijke naar het onverganklijke bestaan. Deze metamorfose verloopt in fasen: Jezus is opgewekt door de Geest van God, Gods gelooft en door de doop deel heeft aan zijn opstanding, heeft ook deel aan deze Geest.' of God' (diakaiosunē tou theou), for example, mentioned in Romans 1:18-3:20, not only accentuates God's saving act (a vertical dimension) but also God's intervention on behalf of the poor and other outcasts through the apostolic mission (the horizontal dimension). The revelation of God is the revelation of the righteousness of God ( $\mathrm{Rm} 1: 17)$ in, among others, the Law (e.g. Ex 22:21-24), the Prophets (e.g., Zch 7:9-10) and the Writings (e.g. Job 24:9). Those affected are the poor without patrons, women without patriarchs, children without parentage and foreigners without a paterfamilias. The pilgrimage to the nations includes all four groups of marginalized people. Blending the concepts of the righteousness of God, begging for the poor, and Paul's apostolic mission helps us to understand why the end of Romans (15:22-33) and its beginning (1:18-3:20) come to a full circle. The vertical dimension of God's saving act merges with the horizontal dimension of God's saving act.

\section{Acknowledgements Competing Interest}

The author declares that he has no financial or personal relationship(s) which may have inappropriately influenced him in writing this paper.

\section{References}

Aristoteles, 1959, 'Rhetorica: 4 BCE', in W.D. Ross (ed.), Arstotelis ars rhetorica, (reprinted), Clarendon Press, Oxford.

Aristoteles, [1894] 1962, 'Ethica Nicomachea: 4 BCE', in I. Bywater (ed.), Aristotelis ethica Nicomachea, pp. 1-224, Clarendon Press, Oxford.

Breytenbach, C., 1986, 'Probleme rondom die interpretasie van die "versoeningsuitsprake" by Paulus', HTS Teologiese Studies/Theological Studies 42(4), 696-704.

Breytenbach, C., 1989, Versöhnung: Eine Studie zur paulinischen Soteriologie, Neukirchner Verlag, Neukrichen-Vluyn. (Wissenschaftliche Untersuchungen zum Neuen Neukirchener Verlag, 60).

Breytenbach, C., 2011, “"For in hope we are saved": Discerning time in Paul's letter to the Romans', in J.G. van der Watt (ed.), Eschatology of the New Testament and some related documents, pp. 181-196, Mohr Siebeck, Tübingen. (Wissenschaftliche Untersuchungen zum Neuen Testament, 2. Reihe).

Byrne, B., 1996, Romans, The Liturgical Press, Collegeville, MN. (Sacra Pagina Series vol. 6, A Michael Glazier Book).

Charles, J.D., 2000, 'Virtue and vice lists', in S.E. Porter \& C.A. Evans (eds.), Dictionary of New Testament background: A compendium of contemporary biblical scholarship pp. 1252-1257, InterVarsity Press, Downers Grove, IL.

Crossan, J.D., 1998, The birth of Christianity: Discovering what happened in the years immediately after the execution of Jesus, HarperSanFrancisco, San Francisco, CA.

Davidson, B., 1967, The analytical Hebrew and Chaldee lexicon, Samuel Bagster \& Sons, London.

Den Heyer, C.J., 1998, Paulus: Man van twee werelden, Uitgeverij Meinema, Zoetermeer.

Doty, W.G., 1973, Letters in primitive Christianity, Fortress Press, Phildelphia, PA.

Dunn, J.D.G., 1998, The theology of Paul the apostle, Eerdmans, Grand Rapids, MI.

Dunn, J.D.G., 1988, Romans, vol. 2, Word Publishers, Dallas, TX. (Word Biblical Commentaries).

Du Toit, A.B., [1992] 2007, 'Romans 1:3-4 and the gospel tradition: A reassessment of the phrase kata pneuma hagiōsunēs', in C. Breytenbach \& D.S. du Toit (ed.), Focusing on Paul: Persuasion and theological design in Romans and Galatians, pp Focusing on Paul: Persuasion and theol

Engberg-Pedersen, T., 2003, 'Paul: virtues \& vices', in J.P. Sampley (ed.), Paul in the Greco-Roman world, pp. 608-634, Trinity Press International, Harrisburg, PA. (A Continuum imprint)

Funk, R.W., 1967, 'The apostolic parousia: Form and significance', in W.R. Farmer C.F.D. Moul \& R.R. Niebuhr (eds.), Christian history and interpretation: Studies presented to John Knox, pp. 249-268, Cambridge University Press, Cambridge.

Geyser, A.S., 1946, 'Teksverbeteringe van die Afrikaanse Bybel', HTS Teologies Studies/ Theological Studies 294, 186-190. 
Gundry, R.H., 2005, 'Matthew: Jewish-Christian or Christian Jewish?', in R.H. Gundry (ed.), The Old is Better: New Testament Essays in Support of Traditional, Gundry (ed.), The Old is Better: New Testament Essays in Support of Traditional,
Interpretations, pp. 111-119, Mohr Siebeck, Tübingen. (Wissenschaftliche Interpretations, pp. 111-119, Mohr Siebeck,
Untersuchungen zum Neuen Testament, 178).

Hahn, F., 2002, Theologie des Neuen Testamentes, Band 1: Die Vielfalt des Neuen Testamentes: Theologiegeschichte des Urchristentums, Mohr Siebeck, Tübingen.

Hahn, F., 2006a, 'Gibt e seine Entwicklung in den Aussagen über die Rechtfertigung bei Paulus?', in Hahn, F. (ed.), Studien zum Neuen Testament, Band II: Bekenntnisbildung und Theologie in urchristlicher Zeit, hrsg. von Jörg Frey, pp. 271-297, Mohr Siebeck, Tübingen. (Wissenschaftliche Untersuchungen zum Neuen Testament, 192).

Hahn, F., [1998] 2006b, 'Gerechtigkeit Gottes und Rechtfertigung des Menschen nach dem Zeugnis des Neuen Testaments', in Hahn, F. (ed.), Studien zum Neuen Testament, Band II: Bekenntnisbildung und Theologie in urchristlicher Zeit, hrsg. von Jörg Frey, pp. 299-312, Mohr Siebeck, Tübingen. (Wissenschaftliche Untersuchungen zum Neuen Testament, 192).

Harding, M., 2003, Early Christian life and thought in social context: A reader, Understanding the Bible and its World, T \& T Clark, London.

Harrington, D.J., 2008, 'Matthew and Paul', in D.C. Sim \& B. Repschinski (eds.) Matthew and his Christian contemporaries, pp. 11-26, T \& T Clark, London. (Library of New Testament Studies, 333).

Hornsby, T.J., 2001, 'Paul and the remedies of idolatry: Reading Romans 1:18-24 with Romans 7', in A.K.M. Adam (ed.), Postmodern interpretations of the Bible: $A$ reader, pp. 219-232, Chalice Press, St Louis, MO

Jewett, R., 2007, Romans: A commentary, Fortress Press, Minneapolis, MN. (Hermeneia).

Joubert, S., 2000, Paul as benefactor: Reciprocity, strategy, and theological reflection in Paul's collection, Mohr Siebeck, Tübingen. (Wissenschaftliche Untersuchungen zum Neuen Testament, 124).

Koester, H., 2007, Paul \& his world: Interpreting the New Testament in its context, Fortress Press, Minneapolis, MN.

Longenecker, B.W., 2007, 'Good news to the poor: Jesus, Paul, and Jerusalem', in T.D. Still (ed.), Jesus and Paul receconnected: Fresh pathways into an old debate, pp. 37-65, Eerdmans, Grand Rapids, MI.

Louw, J.P. \& Nida, E.A. (eds.), 1988, Greek-English Lexicon of the New Testament based on semantic domains, Volume 1: Introduction and domains, United Bible Societies, New York.

Malherbe, A.J., 1986, Moral exhortation: A Greco-Roman sourcebook, ed. W.A. Meeks, Westminster, Philadelphia, PA. (Library of Early Christianity, 4).

Malherbe, A.J., 1992, 'Hellenistic moralists and the New Testament', in ANRW II 26(1), pp. 267-333, De Gruyter, Berlin.
Malina, B.J. \& Pilch, J.J., 2007, Social-science commentary on the letters of Paul, Fortress, Minneapolis, MN.

Meier, J.P., 1978, The vision of Matthew: Christ, church, and morality in the First Gospel, Paulist Press, New York. (Theological Inquiries: Studies in Contemporary Biblical and Theological Problems).

Meier, J.P., 1983, 'Antioch', in R.E. Brown \& J.P. Meier (eds.), Antioch and Rome, pp. 12-86, Paulist Press, New York.

Mohrlang, R., 1984, Matthew and Paul: A comparison of ethical perspectives, Cambridge University Press, Cambridge. (Society for New Testament Studies Monograph Series). http://dx.doi.org/10.1017/CBO9780511520426

Moo, D.J, 1996, The epistle to the Romans, Eerdmans, Grand Rapids, MI. (New International Commentary of the New Testament).

Plato, [5-4 BCE] [1900] 1967, 'Respublica', in J. Burnett (ed.), Platonis opera, vol. 4, St II.327a-621d, Clarendon Press, Oxford.

Przybylski, B., [1980] 2004, Righteousness in Matthew and his world of thought, Cambridge University Press, Cambridge, UK.

Sanders, E.P., 1977, Paul and Palestinian Judaism: A comparison of patterns of religion, SCM, London.

Sanders, E.P., 1992, Judaism: Practice and belief 63 BCE-66 CE, SCM, London.

Sanders, E.P., 2009, 'Covenantal nomism revisited', Jewish Studies Quarterly 1, 25-55.

Schnelle, U., 2003, Paulus: Leben und Denken, De Gruyter, Berlin.

Sim, D.C., 1998, The Gospel of Matthew and Christian Judaism: The history and socia setting of the Matthean community, T\&T Clark, Edinburgh. (Studies of the New Testament and its World).

Sim, D.C., 2002, 'Matthew's anti-Paulinism: A neglected feature of Matthean studies', HTS Teologiese Studies/ Theological Studies 58, 767-783.

Strecker, G., 1979, 'Befreiung und Rechtfertigung: Zur Stellung der Rechtfertigungslehre in der Theologie des Paulus', in G. Stercker (Hrsg.), Eschaton und Historie: Aufsätze, pp. 229-259, Vandenhoeck \& Ruprecht, Göttingen.

Vahrenhorst, M., 2008, Kultische Sprache in den Paulusbriefen, Mohr Siebeck, Tübingen. (Wissenschatliche Untersuchungen zum Neuen Testament, 230).

Van Aarde, A.G., 1992, 'A S Geyser, teologiese dosent 1946-1961', HTS Teologiese Studies/Theological Studies 48(1/2), 159-182.

Van Aarde, A.G., 2005, 'Faith as response to reconciliation - a Pauline perspective', (originally published in Afrikaans), Verbum et Ecclesia 26(1), 222-243.

Vos, J.S., 2005, De betekenis van de dood van Jezus: Tussen seculiere exegese en christelijke dogmatiek, Uitgeverij Meinema, Zoetermeer.

Williger, E., 1992, Hagios: Untersuchungen zur Terminologie des Heiligen in den hellenisch-hellenistischen Religionen, Giesen, Germany. (Religion und Geisteswissenschaft, 19). 